\title{
La protección de la legalidad urbanística y el restablecimiento del orden jurídico perturbado en la legislación urbanística de Andalucía
}

\author{
Valeriano Bermúdez Palomar \\ Letrado de la Diputación Provincial de Jaén \\ Profesor Asociado Derecho Administrativo \\ de la Universidad de Jaén
}

SUMARIO: I.- UBICACIÓN EN EL SISTEMA JURÍDICO URBANÍSTICO. II.- LA PROTEGGIÓN DE LA LEGALIDAD Y LA POTESTAD SANCIONADORA EN MATERIA URBANÍSTICA.

1. Dos realidades independientes aunque coordinadas. 2. Supuestos que dan lugar a la incoación de un expediente de protección de la legalidad urbanística. III.- ACTOS SIN LICENCIA U ORDEN DE EJEGUCIÓN O QUE CONTRAVENGAN SUS CONDICIONES. 1. Planteamiento. 2. La medida cautelar de suspensión. 3. Supuestos que nos podemos encontrar ante las actuaciones sin licencia u orden de ejecución o que contravengan sus condiciones. 4. Trámites procedimentales a seguir en los supuestos de actuaciones sin licencia u orden de ejecución o que contravengan sus condiciones. A. Procedimiento ordinario: obras o usos que pudieran ser compatibles con la ordenación urbanística vigente. a). Requerimiento de legalización. b). Procedimiento de legalización. c). Principio de proporcionalidad. B. Procedimiento simplificado: actuaciones incompatibles con la ordenación urbanística. a). Reposición de la realidad física alterada. b). Procedimiento de reposición de la realidad física alterada. c). Ejecución de la resolución de reposición de la realidad física alterada. d). Cumplimiento por equivalencia. C. Procedimiento excepcional o sumario: obras manifiestamente incompatibles con la ordenación urbanística. a). Supuestos. b). Procedimiento excepcional o sumario de reposición de la realidad física alterada. 5. Competencia para ejercer la potestad de restauración de la legalidad urbanística. A. Competencia general del Municipio. B. Subrogación autonómica en caso de inactividad municipal. 6. Plazos a los que queda sujeto el ejercicio 
efectivo de la potestad de restauración de la legalidad urbanística. A. Plazo para notificar la resolución del procedimiento de restauración de la legalidad urbanística. B. Plazo dentro del cual ha de ejercerse la potestad de protección de la legalidad urbanística. a). El plazo general de caducidad de seis años y la excepción de inexistencia de plazo. b). El comienzo del plazo y la terminación de las obras. c). El transcurso del plazo de seis años y la asimilación a la situación de fuera de ordenación. C. Plazo para llevar a cabo la demolición acordada. IV.LICENCIA U ÓRDENES DE EJEGUCIÓN INCOMPATIBLES CON LA ORDENACIÓN URBANÍSTICA. 1. Planteamiento. 2. Supuestos que pueden darse. A. Anulación de la licencia u orden de ejecución a instancia de interesado mediante la interposición de un recurso administrativo o solicitud de revisión de oficio del art. 102 LPAC. B. Anulación de la licencia u orden de ejecución a instancia de la propia Administración siguiendo los cauces de la revisión de oficio. G. Anulación de la licencia u orden de ejecución a instancia de la Administración del Estado y de la Junta de Andalucía. D. Suspensión por el Alcalde de las obras en curso de ejecución amparadas por una licencia u orden de ejecución. 3. Consecuencias que se derivan de los anteriores procedimientos. V.- CONGLUSIONES. VI.- BIBLIOGRAFÍA.

\section{RESUMEN}

Este trabajo pretende realizar una exposición sistemática y concordada de la regulación de la disciplina urbanística contenida en la Ley de Ordenación Urbanística de Andalucía y su reciente Reglamento de desarrollo, complementada con la doctrina jurisprudencial tanto de Tribunal Supremo como del Tribunal Superior de Justicia de Andalucía.

Palabras clave: Andalucía. Protección legalidad urbanística.

\section{ABSTRAC}

The aim of this work is to carry out a systematic and agreed account of the regulations of the town-planning issue found in de the Law of Urban Regulation of Andalusia and its recent Rule application, complemented with both the law principles of the Supreme Court and those of the High Court of Andalusia.

Key words: Andalusia. Protection urban legality. 


\section{UBICACIÓN EN EL SISTEMA JURÍDICO URBANÍSTICO}

El Derecho urbanístico, tal y como indica CARCELLER FERNÁNDEZ ${ }^{1}$, es un conjunto de normas que, por sí mismas o a través del planeamiento que regulan, establecen el régimen urbanístico de la propiedad del suelo y la ordenación urbana y regulan la actividad administrativa encaminada al uso del suelo, la urbanización y la edificación, distinguiéndose en su contenido cuatro grandes aspectos:

a) Planeamiento urbanístico: clases de planes, contenido, elaboración, aprobación y efectos.

b) Régimen urbanístico de la propiedad del suelo: clasificación y calificación urbanística, régimen de las clases de suelo, derechos y deberes de los propietarios, valoraciones, expropiación forzosa, patrimonio municipal de suelo etc.

c) Gestión urbanística: sistemas de ejecución del planeamiento (compensación, cooperación y expropiación), actuaciones asistemáticas en suelo urbano etc.

d) Disciplina urbanística: bajo esta denominación se recogen un conjunto de medidas de intervención administrativa sobre el uso del suelo tendentes a mantener y, en su caso, a restaurar la legalidad urbanística. A este conjunto de medidas dedica nuestra LOUA ${ }^{2}$ su Título VI, cuya rúbrica es, precisamente, "La Disciplina Urbanística", señalando el art. 168.1 en relación con el 2.2 las potestades administrativas que comporta, a saber:

- La intervención preventiva de los actos de edificación o construcción y uso del suelo, vuelo y subsuelo. Esto es, todo lo referente a las licencias urbanísticas.

- La inspección de la ejecución de los actos sujetos a intervención preventiva.

- $\quad$ La protección de la legalidad urbanística y restablecimiento del orden jurídico perturbado.

- La sanción de las infracciones urbanísticas.

Sin embargo, no aparecen en este Título las potestades referentes a la conservación y rehabilitación, que también son un medio para hacer efectivos ciertos deberes urbanísticos que, no obstante, aparecen regulados en el capítulo $\mathrm{V}$

\footnotetext{
${ }^{1}$ CARCELLER FERNÁNDEZ, Antonio, Introducción al Derecho Urbanístico, Tecnos, Madrid 1992, pag. 17.

${ }^{2}$ Ley 7/2002, de 17 de diciembre, de Ordenación Urbanística de Andalucía.
} 
del Título IV de la Ley al tratar de la ejecución de los instrumentos de planeamiento, si bien, con CASTILLO BLANCO ${ }^{3}$, podrían considerarse que tienen un mejor tratamiento sistemático en el Título VI. Por otro lado, aunque las sanciones son enumeradas por el art. 168 de la Ley como una de las potestades de la disciplina urbanística, se regulan, sin embargo, en un Título aparte, el VII.

El Decreto 60/2010, de 16 de marzo, por el que se aprueba el Reglamento de Disciplina Urbanística de la Comunidad Autónoma de Andalucía ha seguido la línea marcada por la LOUA, estructurando el contenido del Reglamento en tres títulos: un Título Preliminar, dedicado a las disposiciones generales, y dos Títulos más, el primero destinado a la Disciplina urbanística y el segundo a las Infracciones y Sanciones.

Por tanto, queda claro que este trabajo se centra en la tercera de las potestades que se comprenden dentro de lo que conocemos como Disciplina Urbanística, esto es, "la protección de la legalidad urbanística y el restablecimiento del orden jurídico perturbado", que se encuentra regulada en el Capítulo V del Título VI de la LOUA (arts. 181 a 190) y en el Capítulo V del Título I del RDUCA (arts. 36 a 59).

\section{LA PROTECGIÓN DE LA LEGALIDAD Y LA POTESTAD SANGIONADORA EN MATERIA URBANÍSTICA}

\section{Dos realidades independientes aunque coordinadas.}

Toda vulneración de la legalidad urbanística da lugar, o debe dar lugar, habida cuenta que el ejercicio tanto de la potestad de disciplina urbanística como de la sancionadora constituyen un auténtico deber para la Administración (art. 192 LOUA), a dos expedientes, uno sancionador, y por tanto, de carácter punitivo, en el que se va a dilucidar si esa vulneración de la legalidad urbanística es constitutiva o no de una infracción urbanística, y en su caso, merecedora de la correspondiente sanción. Y otro de mera protección de la legalidad urbanística, que no tiene carácter sancionador, y cuya única finalidad es restablecer la legalidad urbanística vulnerada, bien legalizando, o si ello no es posible, reponiendo la realidad física alterada. Ambos procedimientos se tramitarán de

\footnotetext{
${ }^{3}$ CaStillo Blanco, Federico, Derecho Urbanístico de Andalucia, Tirant Lo Blanch, Valencia 2003, pag. 519.
} 
forma independiente aunque coordinada (arts. 186.2 LOUA y 54.2 RDUCA), pero sólo el primero deberá suspenderse en caso de que por los mismos hechos se esté tramitando una causa penal, pues de lo contrario se incurriría en una vulneración del principio non bis in idem, y así lo indican los arts. 65.5 y 37.3 del RDUCA, en relación con el art. 42 del Texto Refundido de la Ley de Suelo de $2008^{4}$. Por consiguiente, el procedimiento de protección de la legalidad urbanística podrá continuar con su tramitación, incluso adoptándose la medida cautelar de suspensión del acto que se esté llevando a cabo vulnerando la legalidad urbanística, tal y como prevé el art. 181 de la LOUA y 42 del RDUCA. A este respecto la jurisprudencia es pacífica, reiterada y uniforme, sirva de botón de muestra la Sentencia del TSJ de Cataluña de 30 de septiembre de 2010, LA LEY 196195/2010, o la Sentencia del TSJ de Andalucía de 19 de noviembre de 2007, LA LEY 345226/2007.

Finalmente, a consecuencia de que nos encontramos ante dos procedimientos independientes pero que han de tramitarse de forma coordinada, el inicio del procedimiento de protección de la legalidad urbanística no interrumpirá el plazo de prescripción de las eventuales infracciones urbanísticas (art. 55 RDUCA). Sin embargo, si en el momento de formularse la propuesta de resolución en el procedimiento sancionador aún no hubiera recaído resolución en el de restauración, se deberá hacer constar expresamente la pendencia de la adopción de las medidas procedentes para el pleno restablecimiento del orden jurídico infringido y, por tanto, en su caso, para la reposición a su estado originario de la realidad física alterada (art. 187 LOUA y 56 RDUCA). Por otro lado, con independencia de que los actos que han dado lugar a la vulneración de la legalidad urbanística sean o no legalizables, si son constitutivos de una infracción urbanística, se impondrá la correspondiente sanción (art. 186.1 LOUA y 54.1 RDUCA).

\section{Supuestos que dan lugar a la incoación de un expediente de protección de la legalidad urbanística.}

Tanto la LOUA como el RDUCA distinguen dos supuestos:

- Actos sin licencia u orden de ejecución o que contravengan sus condiciones: Arts. 181 a 185 de la LOUA, desarrollados por los arts. 42 a 53 del RDUCA.

\footnotetext{
${ }^{4}$ Real Decreto Legislativo 2/2008, de 20 de junio, por el que se aprueba el Texto Refundido de la Ley de Suelo.
} 
- Licencias u órdenes de ejecución incompatibles con la ordenación urbanística: Arts. 189 y 190 de la LOUA, desarrollados por los arts. 57 a $59^{5}$ del RDUCA.

Analicémoslos por separado.

\section{ACTOS SIN LICENCIA U ORDEN DE EJEGUGIÓN O QUE CONTRAVENGAN SUS CONDICIONES}

\section{Planteamiento.}

Nos estamos refiriendo a cualquier acto de parcelación urbanística, urbanización, construcción o edificación e instalación, o cualquier otro acto de transformación o uso del suelo, del vuelo o del subsuelo, que se realice, ejecute, desarrolle o se haya desarrollado sin la aprobación de la correspondiente licencia o, en su caso, sin orden de ejecución, o bien se estén o se hayan llevado a cabo, contraviniendo las condiciones de la licencia u orden de ejecución.

\section{La medida cautelar de suspensión.}

Cuando nos encontremos ante un supuesto de esta naturaleza que esté en curso de ejecución, el Alcalde tiene el deber, tiene la obligación de adoptar la medida cautelar de suspensión inmediata de las obras o el cese del acto o uso en curso de ejecución, realización o desarrollo, así como el suministro de cualesquiera servicios públicos (art. 181 LOUA y 42 RDUCA).

La resolución acordando esta medida, que podemos calificar como cautelarísima o "sorpresiva" en palabras del TSJ de Andalucía en Sentencia de 19 de enero de 2000, LA LEY 18054/2000, pues se adopta sin necesidad de trámite de audiencia previa, puede notificarse, indistintamente, al promotor, al propietario, al responsable o, en su defecto, a cualquier persona que se encuentre en el lugar de ejecución, realización o desarrollo, y esté relacionada con el mismo (art. 181.2 LOUA y 42.2 RDUCA). No obstante, entiendo que esta medida debe adoptarse previa la emisión de los correspondientes informes técnico y jurídico, aunque expresamente no lo exija ni la LOUA ni el RDUCA. Sin embargo, parece razonable que una medida de tal gravedad se adopte con la elemental cautela y garantía que ofrece la intervención de los funcionarios encargados de la emisión de tales informes.

\footnotetext{
${ }^{5}$ Si bien el art. 59 se encuentra mal ubicado sistemáticamente según después se verá.
} 
Naturalmente, el cumplimiento de esta medida provisional es obligatorio y puede llevar aparejado las siguientes consecuencias:

$\left.1^{\circ}\right)$ Se pueden precintar las obras, instalaciones o usos, para lo cual se levantará la correspondiente acta (art. 42.3 RDUCA).

$2^{\circ}$ ) Se dará traslado de la resolución ordenando la suspensión a las empresas suministradoras de servicios públicos, y en todo caso, a las empresas suministradoras de energía eléctrica, agua, gas y servicios de telecomunicaciones para que interrumpan la prestación de dichos servicios. Esta suspensión se mantendrá hasta que el Ayuntamiento les notifique expresamente el otorgamiento de la licencia urbanística, o el levantamiento de la orden de suspensión (art. 181.2 LOUA y art. 42.4. RDUCA).

$3^{\circ}$ ) Si no se acata la orden de suspensión, el Ayuntamiento podrá retirar los materiales de construcción y la maquinaria, que serán depositados en lugar apropiado al efecto, siendo de cuenta del promotor, propietario o responsable del acto correr con los gastos de transporte, depósito y custodia (art. 181.3 LOUA y art. 42.5 RDUCA).

$4^{\circ}$ ) Ante el incumplimiento de la orden de suspensión, también se pueden imponer multas coercitivas, tanto a los sujetos citados en el apartado anterior, como a las empresas suministradoras de servicios públicos, por periodos mínimos de diez días y cuantía, en cada ocasión, del diez por ciento del valor de las obras ejecutadas y, en todo caso y como mínimo, de 600 euros (art.181.4 LOUA y art. 42.6 RDUCA).

$\left.5^{\circ}\right)$ Finalmente, de tal incumplimiento se dará traslado al Ministerio Fiscal a los efectos de exigencia de la responsabilidad que proceda (art. 181.4 LOUA y 42.6 RDUCA). El incumplimiento de la orden de suspensión de las obras puede ser constitutivo de un delito de desobediencia, pero si finalmente el inculpado no fuere condenado, podría imponerse la sanción administrativa muy grave de inobservancia de las medidas cautelares de suspensión (art. 207.D LOUA).

Debemos comentar que la resolución adoptando esta medida cautelar puede hacerse de dos formas, o mejor dicho, adoptarse en dos momentos distintos. De manera independiente y con anterioridad a la incoación del procedimiento de restauración de la legalidad, en cuyo caso nos encontramos ante una de las conocidas medidas provisionales previstas en el art. 72.2 de la LPAC, las cuales deberán ser confirmadas, modificadas o levantadas en el acuerdo de ini- 
ciación del procedimiento, y que a nuestros efectos es el procedimiento de restauración de la legalidad, que deberá efectuarse dentro de los quince días siguientes a su adopción. En todo caso, dichas medidas quedarán sin efecto si no se inicia el procedimiento en dicho plazo o cuando el acuerdo de iniciación no contenga un pronunciamiento expreso acerca de las mismas.

Por consiguiente, una vez adoptada esta medida, y dentro de los quince días siguientes a su adopción, se deberá incoar el correspondiente expediente de restauración de la legalidad urbanística y en dicho acuerdo se deberá confirmar, modificar o levantar dicha medida, pues de lo contrario quedará sin efecto. Esta posibilidad que venimos comentando no estaba expresamente prevista por la LOUA en la redacción originaria de su art. 181.1. Sin embargo, la reciente reforma de dicho precepto operada en virtud de la Ley 2/2012, de 30 de enero, ha recogido expresamente tal posibilidad ${ }^{6}$, que a mi modo de ver ya existía aplicando los preceptos del procedimiento administrativo común en los términos expuestos.

También es posible que la medida se adopte directamente en la misma resolución por la que se incoa el expediente de restauración de legalidad urbanística, como uno de los pronunciamientos de su parte dispositiva. Esto último, será lo habitual.

Por último, debemos comentar que si el Ayuntamiento no adopta esta medida, la Junta de Andalucía a través de la Consejería competente en materia de urbanismo podrá adoptarla previo requerimiento al Alcalde una vez transcurridos diez días desde que se efectuó tal requerimiento (arts. 188.1 LOUA y 43.1 RDUCA).

\footnotetext{
${ }^{6}$ La nueva redacción dada al art. 181.1 de la LOUA por el apartado cuarenta y tres del artículo único de la Ley 2/2012, de 30 de enero, es la siguiente: "Cuando un acto de parcelación urbanística, urbanización, construcción e instalación, o cualquier otro de transformación o uso del suelo, del vuelo o del subsuelo que esté sujeto a cualquier aprobación o a licencia urbanística previas, se realice, ejecute o desarrolle sin dicha licencia aprobación o licencia o, en su caso, sin orden de ejecución, o contraviniendo las condiciones de las mismas, la persona titular de la Alcaldía deberá ordenar, en todo o en la parte que proceda, la inmediata suspensión de las obras o el cese del acto o uso de ejecución, realización o desarrollo, así como del suministro de cualesquiera servicios públicos. Esta medida se adoptará cuando se aprecie la concurrencia de las circunstancias anteriores, incluso con carácter previo al inicio del expediente de restablecimiento del orden jurídico perturbado."
} 


\section{Supuestos que nos podemos encontrar ante las actuaciones sin licencia u orden de ejecución o que contravengan sus con- diciones.}

Cuando nos encontramos ante una actuación sin licencia u orden de ejecución o contraviniendo sus determinaciones se pueden dar distintos supuestos, aunque tal y como ha manifestado REBOLLO $\mathrm{PUIG}^{7}$ en realidad se pueden reducir a dos:

a) Que la actuación no tenga más ilegalidad que la formal de no contar con licencia porque materialmente no es contraria al planeamiento, de manera que es legalizable. La legalidad se restablecerá otorgando a posteriori la licencia correspondiente (de obras, de parcelación, de demolición etc). De esta forma se habrá restaurado la legalidad pues la única ilegalidad era precisamente la falta de la correspondiente licencia urbanística.

b) Que la actuación sea materialmente ilegal por resultar contraria a la legalidad o al planeamiento urbanístico, en cuyo caso lo ejecutado resulta ilegalizable. En este supuesto, para restaurar la legalidad urbanística no habrá más remedio que reponer las cosas al estado anterior, restableciendo la realidad fisica alterada (demolición de lo construido, reconstrucción de lo demolido, reagrupación de lo parcelado etc) e impidiendo los usos prohibidos. Si el particular no ejecuta la resolución administrativa ordenando la reposición de la realidad física alterada, será la Administración la que proceda a su ejecución forzosa, para lo cual, en su caso, se impondrán hasta doce multas coercitivas, y tras la última se acudirá a la ejecución subsidiaria (art. 184 LOUA).

\section{Trámites procedimentales a seguir en los supuestos de actua- ciones sin licencia u orden de ejecución o que contravengan sus condiciones.}

En estos supuestos, la Administración actuará de la siguiente manera (arts. 47 y 48 RDUCA) : en el mismo acuerdo de inicio del procedimiento, adoptado previos los informes técnico y jurídico, que habrá de ser notificado al interesado, se indicará motivadamente si las obras o usos son compatibles o no con la ordenación vigente, o si son manifiestamente incompatibles con la ordenación urbanística. No obstante, esta calificación inicial no es definitiva, pues la

${ }^{7}$ REBOLLO PUIG, Manuel, Derecho Urbanístico y Ordenación del Territorio en Andalucía, Iustel, Madrid, 2007, pag. 478. 
Administración podrá cambiar de opinión a la vista del resultado del procedimiento de protección de la legalidad urbanística. Habitualmente, en este mismo acuerdo se habrá adoptado la medida cautelar de suspensión de las obras o usos, aunque ésta también se puede adoptar de forma separada y con carácter previo a la incoación del procedimiento de restauración de la legalidad según vimos antes, en cuyo caso el mantenimiento de la medida cautelar deberá ser expresamente confirmado, pues de lo contrario quedará sin efecto. En este acuerdo se concederá al interesado plazo de audiencia no inferior a diez ni superior a quince días para que pueda formular alegaciones.

Por tanto, desde el punto de vista estrictamente procedimental pueden darse distintos supuestos, aunque, con GUTIÉRREZ COLOMINA y GUTIÉRREZ JULIÁN ${ }^{8}$, en realidad los podemos reconducir a tres:

a) Un primer supuesto, al que podemos llamar procedimiento ordinario para las obras que pueden resultar compatibles con la ordenación urbanística (arts. 47 y 48 RDUCA). Se trata de aquellos casos en los que nos encontramos con obras o usos que aparentemente pueden resultar compatibles con la ordenación vigente, lo cual no significa que finalmente dichas obras resulten necesariamente legalizadas, pues a la vista del resultado de expediente de restauración y, en su caso, legalización se puede llegar a la conclusión de que las obras o usos resulten finalmente ilegalizables y, por tanto, lo procedente será proceder a la reposición de la realidad física alterada.

b) Un segundo supuesto, al que los autores antes citados denominan procedimiento simplificado para las actuaciones que sean incompatibles con la ordenación urbanística, excluidas las que requieren su tramitación a través del que denominan procedimiento excepcional. El simplificado no aparece expresamente como tal ni en la LOUA ni en el RDUCA, pero podemos inferirlo del art. 47.1 en relación con el 49 del Reglamento.

c) Un tercer supuesto, al que podemos llamar procedimiento excepcional, o mejor sumario o abreviado, dada la celeridad con que se tramita, para aquellas actuaciones manifiestamente incompatibles con la ordenación urbanística (art. 52 RDUCA).

\footnotetext{
${ }^{8}$ GUTIÉRREZ COLOMINA, Venancio y GUTIÉRREZ JULIÁN, Francisco Javier, Comentario sobre el reglamento de disciplina urbanistica de Andalucía, Fundación Asesores Locales, Málaga 2011, pags. 145 y ss.
} 
A. Procedimiento ordinario: obras o usos que pudieran ser compatibles con la ordenación urbanística vigente.

\section{a). Requerimiento de Legalización.}

Cuando las obras o usos pudieran ser compatibles con la ordenación urbanística vigente, se requerirá al interesado para que inste la legalización en el plazo de dos meses, si la actuación es especialmente compleja se podrá ampliar el plazo hasta un máximo de otros dos meses, o bien proceda a ajustar las obras o usos al título habilitante.

Ante el requerimiento de legalización pueden suceder dos cosas: que el interesado inste la legalización o que no la inste.

- Que el interesado inste la legalización o, en su caso, ajuste las obras o usos a la licencia u orden de ejecución, en cuyo caso se suspenderá la tramitación del procedimiento de protección de la legalidad urbanística hasta la resolución del procedimiento de legalización.

- Que el interesado no inste la legalización ni, en su caso, ajuste las obras o usos a la licencia u orden de ejecución. En este supuesto, que no estaba previsto en la LOUA, el RDUCA establece que la Administración procederá a realizar cuantas actuaciones considere necesarias para comprobar la procedencia o no de dicha legalización, actuando de la siguiente forma (art. 47.3 RDUCA):

. Si procede la legalización: acordará la imposición de hasta 12 multas coercitivas hasta que se inste la legalización o se ajusten las obras o usos a las condiciones señaladas. Una vez impuesta la duodécima multa coercitiva sin que el interesado haya instado la legalización, la Administración ordenará la reposición de la realidad física alterada a costa del interesado. Esta orden se dictará directamente tras la duodécima multa coercitiva sin que haya lugar, por tanto, a la reconversión de este procedimiento en simplificado.

. Si no procediera la legalización: se acordará la continuación del procedimiento mediante la reposición de la realidad física alterada de conformidad con el art. 49 del Reglamento. Es decir, el procedimiento ordinario que no ha culminado con la realización de todos sus trámites se reconvierte en el simplificado, siguiéndose sus determinaciones procedimentales hasta la resolución ordenando la reposición de la realidad física alterada.

. Si las obras son manifiestamente incompatibles con la ordenación urbanística, se procederá en la forma prevista en el art. 52 del Reglamento. A mi mo- 
do de ver, este supuesto que aparece en la letra c) del $n^{\circ} 3$ del art. 47 del RDUCA constituye un error sistemático pues, si la Administración entendía que las obras eran manifiestamente incompatibles con la ordenación urbanística, debió advertirlo en el acuerdo de incoación del procedimiento de restauración de la legalidad, según exige el art. 47.1 del RDUCA, y no dar la posibilidad de su legalización, ya que no tiene sentido invitar a legalizar lo que claramente, lo que manifiestamente es ilegalizable.

\section{b). Procedimiento de legalización.}

Los trámites del procedimiento de legalización aparecen en el art. 182.3 de la LOUA, desarrollado por el art. 48 del RDUCA. La solicitud, tramitación y resolución del procedimiento de legalización se regirán por las normas para el otorgamiento de la licencia urbanística, con las siguientes particularidades:

- El inicio del procedimiento de legalización producirá la suspensión del plazo de un año que, según el art. 182.5 de la LOUA, tiene la Administración para resolver el expediente de restauración de la legalidad urbanística. Esta suspensión se mantendrá hasta tanto sea dictada la resolución otorgando o denegando la correspondiente licencia. Si la licencia es finalmente denegada se reanudará el plazo máximo para notificar la resolución del procedimiento de restauración de la legalidad urbanística.

- La resolución del procedimiento de legalización producirá los siguientes efectos:

. Si la licencia fuese otorgada, o se declarase que las actuaciones realizadas se ajustan al título habilitante, las obras se entenderán legalizadas, finalizando el procedimiento de restablecimiento del orden jurídico perturbado. Si se adoptó la medida cautelar de suspensión de las obras, ésta quedará sin efecto y podrán continuar conforme a las determinaciones de la licencia.

. Si la licencia no fuese otorgada, o se declarase que las actuaciones realizadas no se ajustan al título habilitante, se procederá a dictar orden de reposición de la realidad física alterada en los términos previstos en el art. 49 del RDUCA. La expresión "... se procederá a dictar orden de reposición de la realidad fisica alterada..." parece dar a entender, que en este supuesto, tampoco se producirá la reconversión del procedimiento en simplificado, lo cual resulta lógico, habida cuenta que en el procedimiento ordinario de legalización tramitado se han observado todas las garantías que aseguren el acierto de la resolución adoptada, esto es, de la orden de reposición dictada. 


\section{c). Principio de proporcionalidad.}

La LOUA en su art. 182.3 preveía que reglamentariamente se establecerían los supuestos y condiciones en los que, con carácter excepcional y en aplicación del principio de proporcionalidad, quepa la legalización de las actuaciones aún con disconformidades no sustanciales con la ordenación urbanística aplicable, por resultar de imposible o muy dificil reposición. Esta previsión ha sido contemplada en el art. 48.4 del RDUCA, el cual señala que los criterios que habrá que tener en cuenta para determinar si la disconformidad con la ordenación urbanística es o no sustancial, serán los siguientes:

. Superficie que exceda de lo autorizado.

- Visibilidad desde la vía pública.

. Incidencia de la obra edificada en el resto del conjunto edificatorio.

. Solidez de la obra ejecutada.

. Afección a barreras arquitectónicas.

Estos criterios son meramente ejemplificativos de tal modo que nada impide a la Administración tener en cuenta otros criterios. Por otro lado, la redacción excesivamente genérica de estos preceptos nos obliga a recordar la sólida doctrina del TS (Sentencias de 16 de mayo de 1990, LA LEY 32674F/0000, de 28 de noviembre de 2001, LA LEY 3213/2002, o 15 de enero de 2002, LA LEY 2778/2002) acerca de la aplicación del principio de proporcionalidad en los casos de reposición de la realidad física alterada, que podemos sintetizar de la siguiente manera:

- El principio de proporcionalidad expresa, en general, la necesidad de una adecuación o armonía entre el fin de interés público que se persiga y los medios que se empleen para alcanzarlo.

- En el Derecho administrativo, la proporcionalidad se manifiesta en distintos ámbitos, permitiendo una interpretación equilibrada del concepto de interés público.

- En el ámbito de la disciplina urbanística el principio de proporcionalidad opera en dos supuestos:

. Con carácter ordinario, en aquellos casos en los que el ordenamiento jurídico admite la posibilidad de elegir uno entre varios medios utilizables.

. Con carácter excepcional y en conexión con los principios de buena fe y 
equidad, en los supuestos en los que aún existiendo en principio un único medio éste resulta a todas luces inadecuado y excesivo en relación con las características del caso contemplado.

- En los casos de actuaciones que contradicen el planeamiento urbanístico, la Administración resulta obligada a restaurar la realidad física alterada o transformada por medio de la acción ilegal, pues no tiene posibilidad de optar entre dos o más medios distintos, por lo que no resulta de aplicación el principio de proporcionalidad, máxime si tenemos en cuenta la vinculación positiva de la Administración a la Ley, la cual obliga a la Administración a demoler, dados los términos imperativos en que se pronuncian los preceptos legales.

- A modo de conclusión, nuestro TS declara que el principio de proporcionalidad no tiene por finalidad obstaculizar en cualquier caso las medidas de restauración de la legalidad urbanística infringida, sino la de suavizar la aplicación de la norma en aquellos supuestos en los que un leve incumplimiento acarrea muy graves consecuencias, más el principio de proporcionalidad no puede evitar el resultado querido por la norma, que es en el caso presente la demolición de lo abusivamente construido.

Por otra parte, el RDUCA en su art. 48.4 sujeta la aplicación del principio de proporcionalidad a los siguientes límites:

. No se aplicará en los supuestos contemplados en el art. 185.2 de la LOUA, que recordemos se refiere a aquellos atentados a la legalidad urbanística en los que por su gravedad el ejercicio de la potestad de protección de la legalidad urbanística no queda sujeta a plazo.

. Tampoco se aplicará a los sujetos que hayan sido sancionados por infracción urbanística grave o muy grave, impuesta por resolución firme. Esa firmeza, obviamente, la debemos entender en vía administrativa.

La resolución que ponga fin al procedimiento de legalización en la que se aplique el principio de proporcionalidad se dictará, como cualquier otra, previos los informes técnico y jurídico, los cuales, deberán valorar expresamente el grado de disconformidad existente con la ordenación urbanística aplicable, debiendo, en definitiva, la resolución motivar la aplicación del principio de proporcionalidad, y en su caso, establecer la indemnización sustitutoria al aprovechamiento urbanístico materializado sin título. Dicha indemnización deberá abonarse con independencia de las sanciones por infracciones urbanísticas que, en su caso, procedan, y además el infractor al que se le aplique el 
principio de proporcionalidad no se le aplicará la reducción del 75\% de la sanción impuesta a los autores de hechos constitutivos de infracciones urbanísticas que no obstante resultan legalizables. Esta previsión resulta lógica habida cuenta que en los supuestos en los que se aplique el principio de proporcionalidad la legalización ha sido meramente parcial, por lo que no cabe que perciba los beneficios de una legalización total.

B. Procedimiento simplificado: actuaciones incompatibles con la ordenación urbanística.

\section{a). Reposición de la realidad fisica alterada.}

En el caso de que no proceda la legalización, bien sea porque desde el mismo acuerdo de incoación del procedimiento de protección de la legalidad urbanística así se haya entendido conforme a lo establecido en el art. 47.1 del RDUCA, o bien porque el procedimiento ordinario se reconvierta en simplificado según vimos anteriormente, procederá restaurar la realidad física alterada, siguiendo los trámites del procedimiento de reposición de la realidad física alterada previstos en el art. 49 del RDUCA.

Los supuestos contemplados en este procedimiento hay que distinguirlos de aquellos casos en los que nos encontramos con actuaciones manifiestamente incompatibles con la ordenación urbanística, que ya vimos se tramitarán siguiendo los cauces del procedimiento excepcional o sumario al que después nos referiremos. Ahora se trata de actuaciones en las que desde el comienzo se denota su incompatibilidad con la ordenación urbanística, aunque sin tratarse de uno de los supuestos previstos en el art. 52 del RDUCA, o bien, puede suceder que el procedimiento de protección de la legalidad se iniciara siguiendo los cauces del ordinario, pero finalmente se reconvierta en este procedimiento simplificado. Hay que destacar que no se trata de procedimientos estancos, sino más bien de procedimientos interconectados de forma que nada impide a la vista de las actuaciones practicadas en el procedimiento que éste finalmente se reconvierta en ordinario, procediendo, en su caso, a la legalización de la obra o actuación, o al contrario, que el iniciado por ordinario se reconvierta en simplificado. De lo que se trata, en definitiva, es de asegurar, en la medida de lo posible, el acierto y la justeza de la resolución que se dicte, bien sea legalizando, bien sea reponiendo la realidad física alterada.

\section{b). Procedimiento de reposición de la realidad fisica alterada.}

Según vamos a comprobar este procedimiento es tan garantista para el in- 
teresado como el ordinario. Es decir, aunque la Administración haya considerado que las obras son ilegalizables, el interesado va a tener la posibilidad de intentar demostrar lo contrario.

En particular, dice el RDUCA en su art. 49.1 que la resolución que ponga fin al procedimiento de reposición de la realidad física alterada se dictará previos los correspondientes informes técnico y jurídico, transcurrido el plazo de audiencia y, en su caso, la práctica de la prueba. Hay que tener en cuenta que en el art. 183.2 de la LOUA se dice que las propuestas de resolución que se formulen en los procedimientos de restablecimiento del orden jurídico perturbado o de reposición de la realidad física alterada deberán incluir, cuando proceda, las disposiciones sobre plazos y otras materias que se estimen precisas para la reposición, a costa del interesado, de las cosas al estado inmediatamente anterior a la vulneración de la legalidad urbanística, incluida la demolición o en su caso reconstrucción. Quiere decirse, por tanto, que una vez practicada la prueba e incorporados, en su caso, cualesquiera informes que haya podido solicitar el órgano competente, además de los citados informes técnico y jurídico, o sea, una vez instruido el procedimiento, se pondrá de manifiesto al interesado para que, conforme a lo dispuesto en el art. 84.1 y 2 de la LPAC formule las alegaciones y presente los documentos y justificantes que estime pertinentes, a continuación se emitirá la correspondiente propuesta de resolución y finalmente el órgano competente dictará la resolución. La resolución ordenando la reposición de la realidad física alterada deberá observar el contenido previsto en el art. 89 de la LPAC, y podrá adoptar alguna o algunas de las medidas previstas en el art. 49.2 del RDUCA, que no tienen carácter excluyente:

. Demolición de las obras ilegales y correcta gestión de los residuos derivados de la misma.

. Eliminación de los elementos que materialicen la parcelación, con roturación de caminos y desmantelamiento de los servicios, infraestructuras u otras instalaciones ilegales.

. Reposición de plantas, árboles y arboledas.

. Cuando se trate de carteles y vallas, desmontaje y retirada de estos.

. En movimiento de tierras, la reposición de la configuración de los terrenos a su estado anterior, con restauración de la cubierta vegetal.

. En el caso de talas e incendios de masas arbóreas, la reposición consistirá 
en la restauración de la cubierta vegetal preexistente con las mismas especies y en la misma densidad a las especies dañadas, salvo que por el órgano competente en materia forestal de la Administración autonómica andaluza, se determine otro modo de restablecimiento. Siempre que en el mercado existan ejemplares con porte o edad similar a los dañados, se recurrirá a su trasplante en lugar de la plantación o siembra.

. Reconstrucción de las edificaciones protegidas por catálogos o por la legislación sectorial, que la persona interesada haya derribado de forma ilegal. Si se trata de una construcción catalogada o de interés cultural, la reconstrucción se realizará conforme a los criterios que determine el órgano competente en materia de patrimonio histórico de la Administración autonómica andaluza, sin perjuicio de las competencias que puedan corresponder a otras Administraciones públicas que asimismo, fijará, si resulta imposible dicha restauración, la cuantía económica del daño producido, cuyo ingreso se exigirá al infractor, debiendo destinarse su importe a la conservación de otros bienes de interés histórico-artístico conforme a lo prevenido por la legislación en materia de patrimonio histórico. Dicha indemnización deberá abonarse con independencia de las sanciones por infracciones urbanísticas que, en su caso, procedan.

. Reconstrucción de partes de edificios, instalaciones y otras construcciones que, habiéndose demolido de forma ilegal por la persona interesada, sean necesarias para el funcionamiento de los servicios públicos, constituyan partes estructurales de los edificios o garanticen la seguridad de las personas.

. Cese inmediato de los usos u actos y, en su caso, clausura y precinto de edificaciones, establecimientos o sus dependencias.

. En el caso de parcelaciones urbanísticas en terrenos que tengan el régimen del suelo no urbanizable, el restablecimiento del orden jurídico perturbado se llevará a cabo mediante la demolición de las edificaciones que la integren y reagrupación de las parcelas, a través de una reparcelación forzosa de las que han sido objeto de dichos actos de previa parcelación. Los actos y negocios jurídicos que hayan dado lugar a la reparcelación deberán invalidarse, bien mediante voluntad de las partes, o en su caso, mediante resolución judicial. A estos efectos, la Administración competente ostentará la legitimación activa para instar ante la jurisdicción ordinaria la anulación de dichos títulos, y estará facultada para instar la constancia en el Registro de la Propiedad y en el Catastro Inmobiliario, en la forma y a los efectos previstos en la legislación correspondiente, de la reparcelación forzosa, sin perjuicio de las responsabilidades que procedan. 
c). Ejecución de la resolución de reposición de la realidad fisica alterada.

La ejecución de esta resolución aparece regulada en los artículos 183.3 y 4 de la LOUA y 50 del RDUCA. Esta resolución deberá fijar un plazo no superior a dos meses para que su destinatario lleve a cabo las medidas acordadas en la misma, advirtiéndole que transcurrido este plazo sin haber procedido a la restauración, se le impondrán hasta doce multas coercitivas con una periodicidad mínima de un mes y cuantía, en cada ocasión, del diez por ciento del valor de las obras realizadas y, en todo caso, como mínimo de 600 euros, y que una vez impuesta la última multa se procederá a la ejecución subsidiaria por la Administración pública a costa del interesado.

Si finalmente hubiera que llevar a cabo la ejecución subsidiaria, los obligados a cumplir la resolución acordando la reposición de la realidad física alterada deberán, previo requerimiento de la Administración pública actuante, proceder al desalojo de la construcción o edificación objeto de la misma en el día indicado por el órgano competente. No obstante, si el interesado hiciera caso omiso del requerimiento y la Administración para ejecutar la orden de reposición de la realidad física alterada tuviera que acceder, sin consentimiento del interesado, al domicilio o lugar para cuyo acceso sea preciso su consentimiento, la Administración deberá obtener previamente la correspondiente autorización judicial, cuyo otorgamiento compete al Juzgado de lo Contencioso-administrativo, según establece el art. 8.6 de la LJCA en relación con el 91.2 de la LOPJ, sin que con ocasión de esta autorización se pueda ejercer control sobre la legalidad del acto originario que se pretende ejecutar (STSJ de Andalucía de 19 de mayo de 2003, LA LEY 89233/2003).

El deber de desalojo incluye también el de retirar cuantos bienes muebles y semovientes se hallen en el inmueble objeto de la medida de reposición de la realidad física alterada, teniendo de lo contrario los mismos el carácter de bienes abandonados a los efectos de proceder a la ejecución de la resolución sin mayores dilaciones. Respecto al carácter de bienes abandonados hay que tener en cuenta el régimen previsto para los mismos por el art. 610 del Código civil al señalar que "Se adquieren por la ocupación los bienes apropiables por su naturaleza que carecen de dueño, como los animales que son objeto de la caza y pesca, el tesoro oculto y las cosas muebles abandonadas." Quiere decirse, por consiguiente, que el Ayuntamiento adquirirá la propiedad de los bienes muebles y semovientes que se encuentren abandonados en el inmueble, y a los que resulten inservibles se les dará el tratamiento previsto para los residuos en la Ley 22/2011, de 28 de julio, de residuos y suelos contaminados. 
De esta resolución se dará traslado a las compañías suministradoras de servicios urbanos para que retiren definitivamente el suministro. Asimismo, la Administración pública competente estará facultada para instar la constancia de dicha resolución en el Registro de la Propiedad y en el Catastro Inmobiliario.

Según el art. 183.4 de la LOUA y 49.4 del RDUCA, si los interesados acataran la resolución y repusieren la realidad física o jurídica alterada por sí mismos tendrán derecho a la reducción en un cincuenta por ciento de la multa que deba imponerse o se haya impuesto en el procedimiento sancionador o a la devolución del cincuenta por ciento del importe correspondiente de la que ya hubieran satisfecho, así como, en su caso, a la minoración o extinción de las sanciones accesorias previstas en el art. 209 de la LOUA. Esta previsión hay que ponerla en conexión con el art. 59 del RDUCA, el cual se encuentra mal ubicado sistemáticamente pues debería formar parte del art. 49 y no incluirse como el último artículo del Capítulo V, del Título I del Reglamento. Así el $n^{\circ} 1$ de este artículo aclara que la reducción de las sanciones no afectará a otras infracciones concurrentes tales como la obstrucción a la función inspectora o la inobservancia de la medida cautelar. El $\mathrm{n}^{\circ} 2$ señala que para la aplicación de las reducciones de las sanciones la Administración comprobará el cumplimiento de las medidas que a tal fin se hayan ordenado en la resolución del procedimiento de restauración de la realidad física alterada, lo cual es lógico, pues no se va a otorgar el beneficio de la reducción de la sanción si previamente la Administración no ha comprobado que el interesado ha repuesto la realidad física alterada.

Por último, el $\mathrm{n}^{\circ} 3$ contempla un nuevo supuesto de reducción de la sanción, no previsto en la LOUA, al señalar que "...la sanción se reducirá en un cincuenta por ciento de su cuantía, a solicitud del sujeto infractor, cuando se cumplan acumulativamente los siguientes requisitos:

a) Que el infractor muestre por escrito su conformidad con la sanción y abone el importe de la multa en el plazo máximo de un mes, contado a partir de la notificación de la sanción.

b) Que el infractor se comprometa a restaurar el orden infringido a su situación inicial en los plazos que le señale la Administración y garantice este compromiso mediante aval del cien por cien del importe de las obras o actuaciones necesarias."

Esta garantía se cancelará por la Administración cuando el obligado hubiera dado cumplimiento a las medidas que a tal fin se hayan ordenado en la resolución del procedimiento de restauración de la realidad física alterada. El incumplimiento de tales medidas dará lugar a la ejecución de la garantía, sin perjuicio de las responsabilidades que en otro orden pudieran derivarse. 


\section{d). Cumplimiento por equivalencia.}

Por último, el art. 51 del RDUCA regula el denominado cumplimiento por equivalencia. Esta forma de cumplir la resolución ordenando la reposición de la realidad física alterada se da cuando concurran causas que impidan material o legalmente ejecutar aquella resolución. En estos supuestos el órgano competente adoptará las medidas necesarias que aseguren en lo posible la efectividad del restablecimiento del orden jurídico perturbado, sin perjuicio de la potestad jurisdiccional de hacer ejecutar lo juzgado, en los casos en que haya recaído resolución judicial firme, supuesto sobre el que después volveremos.

Antes de adoptar tales medidas, el órgano competente deberá recabar los correspondientes informes técnico y jurídico que valorarán la imposibilidad material o legal y fijarán, en su caso, la indemnización por equivalencia en la parte que no pueda ser objeto de cumplimiento pleno, pudiendo consistir en una cantidad en metálico, o en la cesión de una porción de terreno o edificación equivalente al aprovechamiento materializado sin título. La valoración del aprovechamiento urbanístico materializado indebidamente se realizará de conformidad con la legislación vigente en materia de valoraciones. Dicha indemnización deberá abonarse con independencia de las sanciones por infracciones urbanísticas que, en su caso, procedan, y además el infractor al que se le aplique el cumplimiento por equivalencia no tendrá derecho a la reducción del $75 \%$ de la sanción impuesta a los autores de hechos constitutivos de infracciones urbanísticas que no obstante resultan legalizables. Esta previsión resulta lógica habida cuenta que en los supuestos en los que se aplique el cumplimiento por equivalencia, al igual que sucedía cuando se aplicaba la proporcionalidad, la reposición ha sido meramente parcial, por lo que no cabe que perciba los beneficios de una reposición total.

En los supuestos en los que haya recaído resolución judicial firme, nos encontraremos ante un supuesto de ejecución de Sentencia regulado en los arts. 103 y ss de la LJCA. Conviene recordar que el incidente de inejecución de la sentencia por imposibilidad material o legal de ejecutarla ha de ser planteado por la Administración dentro del plazo de dos meses contemplado en los arts. 104.2 y 105.2 de la LJCA, habiendo declarado el TS en Sentencia de 8 de octubre de 2008, LA LEY 189503/2008, “... Sobre esta cuestión del plazo para instar la declaración de inejecutabilidad de la sentencia por imposibilidad legal o material, esta Sala ha mantenido una doctrina vacilante e incluso contradictoria, aunque en las últimas Sentencias se ha inclinado por la relevancia y trascendencia del plazo legal para pedirla, considerándolo preclusivo y perentorio salvo que se justifique cumplidamente la razón de no haberse instado el incidente de inejecución en el plazo de dos meses o en el que viniese fijado en 
la propia sentencia a ejecutar.....con tal plazo preclusivo se pretende evitar la inseguridad en cuanto a la ejecución de las Sentencias y evitar la promulgación de disposiciones o la adopción de actos contrarios a los pronunciamientos de las sentencias con la finalidad precisamente e eludir su cumplimiento, los que el art. 103.4 de la misma Ley sanciona con la nulidad radical..."

Por otro lado, hay que tener presente que, conforme a lo dispuesto en el art. 19 del Texto Refundido de la Ley de Suelo, en relación con el art. 168.2 de la LOUA $^{9}$ y el 38 del RDUCA, las medidas de protección de la legalidad tienen carácter real, por lo que "... frente a los deberes derivados del incumplimiento de la legalidad urbanística no cabe aducir la condición de tercero adquirente de buena fe amparado por el acceso de su derecho de dominio al Registro de la Propiedad, puesto que, conforme al principio de subrogación de los sucesivos adquirentes en el cumplimiento de los deberes impuestos por el ordenamiento urbanístico, la demolición de lo indebidamente construido no sólo pesa sobre quien realizó la edificación ilegal sino sobre los sucesivos titulares de la misma, sin perjuicio de la responsabilidad en que aquél hubiese podido incurrir por los daños y perjuicios causados a éstos..." (STS de 26 de septiembre de 2006, LA LEY 119633/2006).

Por otro lado, según la STS de 5 de abril de 2001, LA LEY 6539/2001, “... sobre el problema más concreto de si una modificación del planeamiento origina la imposibilidad jurídica de ejecución de una sentencia, cuando pretende legalizar aquello que la sentencia anuló, del examen de la jurisprudencia de este Tribunal Supremo solo puede concluirse lo siguiente: esa modificación no será causa de inejecución de la sentencia si ha sido realizada con la intención de incumplir la sentencia, o mejor, con la intención de que ésta no se ejecute..."

Por último, nuestro TS en Sentencia de 30 de octubre de 2008, LA LEY $175993 / 2008$, ha manifestado que “... tratándose de obras realizadas al amparo de una licencia que contraviene normas urbanísticas, la anulación de ésta comporta la obligación de demolición de aquéllas; de suerte que, ni la Sentencia que acuerda ésta, aunque no hubiera sido pedida, es incongruente, ni se rebasa el sentido del título ejecutivo cuando se ordena tal demolición en la fase de ejecución pese a que el título sólo contuviera explícitamente el pronunciamiento anulatorio de la licencia..."

\footnotetext{
${ }^{9}$ La LOUA en su redacción originaria no contenía previsión al respecto. No obstante, el apartado cuarenta del artículo único de la Ley 2/2012, de 30 de enero, de modificación de la Ley 7/2002, de 17 de diciembre, de Ordenación Urbanística de Andalucía, ha añadido un nuevo apartado 2 al art. 168 de la misma con la siguiente redacción: "2. Las medidas de protección de la legalidad urbanística y el restablecimiento del orden jurídico perturbado tienen carácter real y alcanzan a las terceras personas adquirentes de los inmuebles objeto de tales medidas dada su condición de subrogados por ley en las responsabilidades contraídas por la persona causante de la ilegalidad urbanistica, de conformidad con la normativa estatal al respecto."
} 
C. Procedimiento excepcional o sumario: obras manifiestamente incompatibles con la ordenación urbanística.

\section{a). Supuestos.}

Cuando las obras sean manifiestamente incompatibles con la ordenación urbanística carece de sentido requerir al interesado para que pida una licencia que se sabe habrá que denegarle. Por ello, una vez acreditado que las obras ejecutadas son manifiestamente ilegalizables, la jurisprudencia del TS ya había declarado que "...puede acordarse la demolición de lo construido prescindiendo de un trámite de legalización claramente inútil..."(STS de 18 de julio de 2002, LA LEY 136160/2002 y 11 de octubre de 2001, LA LEY 181310/2001). En idénticos términos pueden verse las Sentencias del TSJ de Andalucía, con sede en Granada, de 30 de septiembre de 2002, LA LEY 159810/2002, de 30 de julio de 2003, LA LEY 132789/2003 y 4 de octubre de 2010, LA LEY $267674 / 2010$.

La LOUA reguló este supuesto en su art. 183.5, a raíz de la reforma operada en el mismo por medio de la Ley 13/2005, al decir que "El Ayuntamiento o la Consejería con competencias en materia de urbanismo, en su caso, sin perjuicio de la correspondiente medida de suspensión acordada, dispondrán la inmediata demolición de las actuaciones de urbanización o edificación que sean manifiestamente incompatibles con la ordenación urbanística, previa audiencia del interesado, en el plazo de un mes."

El desarrollo reglamentario de este precepto ha venido a aclarar qué debemos entender por actuaciones manifiestamente incompatibles con la ordenación urbanística. Según el art. 52.2 del RDUCA serían las siguientes:

. Cuando exista una previa resolución administrativa denegatoria de la licencia para la ejecución de las obras objeto del procedimiento.

. Cuando la ilegalidad de las obras o edificaciones resulte evidente de la propia clasificación o calificación urbanística y, en cualquier caso, las actuaciones de parcelación o urbanización sobre suelos no urbanizables, y cualesquiera otras que se desarrollen sobre terrenos destinados por el planeamiento a sistemas generales o dotaciones públicas.

. En los supuestos de actos sujetos a licencia urbanística realizados sobre terrenos de dominio público sin haber obtenido previamente la correspondiente concesión o autorización demanial. 
La gravedad de los supuestos contemplados justifica que se ponga en manos de la Administración un instrumento de actuación más contundente en términos de celeridad que el previsto para los supuestos que han de tramitarse por el que hemos denominado procedimiento simplificado.

\section{b). Procedimiento excepcional o sumario de reposición de la realidad fisica alterada.}

El procedimiento sumario de reposición de la realidad física alterada se iniciará mediante acuerdo declarativo de la causa de incompatibilidad con la ordenación urbanística, fundamentado en los correspondientes informes técnico y jurídico. En ese mismo acuerdo se concederá trámite de audiencia a los interesados por un periodo no inferior a diez días ni superior a quince. Hasta aquí la tramitación es idéntica a la del simplificado. En los trámites que a continuación se exponen es en los que aparece la celeridad a la que antes nos referimos, pues en el plazo de un mes a contar desde la notificación del acuerdo de inicio del procedimiento, se procederá a dictar resolución acordando la demolición de las actuaciones de urbanización o edificación, debiendo cumplirse el mandato de la resolución en el plazo señalado en la misma, que en ningún caso será superior a dos meses. Conviene destacar que la brevedad del plazo de que dispone la Administración para dictar la resolución, un mes desde que notificó el acuerdo de incoación del procedimiento, condiciona la tramitación ulterior. De entrada, hay que tener en cuenta que más de la mitad de este plazo se consumirá con el trámite de audiencia de diez a quince días hábiles, por lo que para poder cumplir con el plazo de un mes debemos entender que no resultan aplicables las reglas del procedimiento administrativo común sobre proposición y práctica de prueba, no quedando tampoco claro si deberá mediar o no propuesta de resolución, aunque me decanto a favor de la obligatoriedad de su existencia a tenor de la literalidad del art. 183.3 de la LOUA que parece exigirla en todos los procedimientos de restablecimiento del orden jurídico perturbado o de reposición de la realidad física alterada, no pudiendo el Reglamento contradecir en este aspecto a la norma de superior rango.

En el supuesto de que el interesado no cumpla la orden de reposición de la realidad física a su estado anterior en el plazo que se le haya concedido, nunca superior a dos meses, se procederá a la ejecución subsidiaria de lo ordenado, sin que haya lugar a la imposición de multas coercitivas lo cual constituye otra diferencia con el procedimiento simplificado en el que recordemos con carácter previo a la demolición había que imponer hasta doce multas coercitivas. 


\section{Competencia para ejercer la potestad de restauración de la le- galidad urbanística.}

A. Competencia general del Municipio.

La competencia para proteger la legalidad urbanística y restaurar el orden jurídico perturbado corresponde con carácter general al Municipio a tenor de lo dispuesto en el art. 25.2.d) de la LBRL, 92.2.a) del Estatuto de Autonomía de Andalucía y 9.1.g) de la Ley de Autonomía Local de Andalucía ${ }^{10}$. Cuestión distinta es si esta competencia debe estar o no en manos de los municipios, y en particular, en los de menor población, máxime si tenemos en cuenta que los escándalos urbanísticos y la crisis que vivimos está alentando inquietantes tendencias contrarias a la autonomía local, por lo que los denominados por RIVERO YSERN ${ }^{11}$ nuevos planteamientos sobre la articulación normativa de las competencias y la autonomía local que descansaría no tanto sobre el eje Ley estatal- Ley autonómica, sino sobre el binomio Estatuto-Ley autonómica de Régimen Local, parecen estar superándose a una velocidad vertiginosa, de tal forma, que las ideas que abogaban por otorgar el máximo protagonismo a los Estatutos de Autonomía en la definición de las competencias locales, han pasado a ser en poco menos de cuatro años unas tendencias legendarias.

En cuanto a qué órgano municipal tiene atribuida esta función, con anterioridad a la LOUA y las últimas reformas de la LBRL, se decía que la competencia para legalizar correspondía al Alcalde, al ser el órgano que tenía la competencia para otorgar las licencias urbanísticas. Sin embargo, si de lo que se trataba era de reponer la realidad física alterada mediante la demolición, cierta jurisprudencia, como por ejemplo la STS de 13 de noviembre de 1996, LA LEY 2862/1997, atribuía la competencia al Pleno del Ayuntamiento. No obstante, tal y como ha señalado REBOLLO PUIG ${ }^{12}$, esta jurisprudencia se sustentaba en los arts. 184 y 185 del Texto Refundido de la Ley de Suelo de 1976, de los cuales se infería la competencia del Ayuntamiento para ordenar la demolición ${ }^{13}$. Pese a todo, siguiendo al autor citado, hoy en día la situación es

${ }^{10}$ El Estatuto de Autonomía de Andalucía fue aprobado mediante Ley Orgánica 2/2007, de 19 de marzo, de reforma del Estatuto de Autonomía para Andalucía (LA LEY 2349/2007), y la Ley de Autonomía Local de Andalucía se aprobó mediante Ley 5/2010, de 11 de junio (LA LEY 13083/2010)

${ }^{11}$ RIVERO YSERN, José Luís, Manual de Derecho Local, Civitas, Cizur Menor (Navarra)m 2010, pag. 213.

12 REBOLLO PUIG, Manuel, op. cit.pag. 486.

${ }^{13}$ En concreto decía el art. 184.4 que "Si el Ayuntamiento no procediera a la demolición en el plazo de un mes, contado desde la expiración del término al que se refiere el número precedente, o desde que la licencia fuese denegada por los motivos expresados, el Alcalde o el Gobernador civil dispondrá directamente dicha demolición a costa asimismo del interesado." 
distinta, en primer lugar porque la LOUA no habla en ningún momento de la competencia del Pleno sobre esta materia, y por otro lado, porque las últimas reformas de la LBRL han reforzado las atribuciones del Alcalde en detrimento del Pleno. A este respecto debemos recordar que el art. 21.1.s) y 124.4.ñ) de la LBRL atribuyen a los Alcaldes tanto de municipios de régimen común, como de régimen especial, la denominada competencia residual, lo cual quiere decir que corresponderá a los Alcaldes el ejercicio de todas aquellas competencias que la legislación del Estado o de las CGAA asignen al Municipio y no atribuyan a otros órganos municipales.

B. Subrogación autonómica en caso de inactividad municipal.

Ante la secular dejadez de funciones en que han venido incurriendo buena parte de los municipios de nuestra geografía, unas veces por falta de capacidad técnica y económica y otras debido a razones más espurias, ha sido tradicional que el legislador previera una suerte de sustitución de la autoridad municipal por parte de otras Administraciones superiores, en caso de inactividad del ente local ante un acto de vulneración de la legalidad urbanística. La LOUA ha mantenido esta línea en su art. 188, desarrollado por el art. 43 del RDUCA, que prevé una subrogación autonómica ${ }^{14}$, de modo que la Consejería competente en materia de urbanismo puede ejercer esta competencia si, tras requerir al Alcalde para que actúe, continúa la pasividad municipal transcurrido un mes desde tal requerimiento. Igual previsión se contiene en el art. 52.4 del RDUCA para el caso de las obras manifiestamente incompatibles con la ordenación urbanística, sólo que en este caso la Comunidad Autónoma actuará si la Administración municipal no lo hace en el plazo de diez días a contar desde el requerimiento. Idéntico plazo de diez días resultaba aplicable al supuesto de que el Alcalde no adoptara la medida cautelar de suspensión, según vimos al tratar de esta medida (art. 43.1 RDUCA).

\footnotetext{
${ }^{14}$ En concreto los actos o usos que legitiman la intervención autonómica son, según el art. 188.1 de la LOUA, los siguientes:

Los que supongan una actividad de ejecución realizada sin el instrumento de planeamiento preciso para su legitimación.

Los que tengan por objeto una parcelación urbanística en terrenos clasificados como suelo no urbanizable.

Los que supongan una afección de las previstas en el art. 185.2.B de la LOUA.
} 


\section{Plazos a lo que queda sujeto el ejercicio efectivo de la potes- tad de restauración de la legalidad urbanística.}

A. Plazo para notificar la resolución del procedimiento de restauración de la legalidad urbanística.

Ya vimos como el art. 182.5 de la LOUA establece que "El plazo máximo en el que debe notificarse la resolución expresa que recaiga en el procedimiento de restablecimiento del orden jurídico perturbado será de un año a contar desde la fecha de su iniciación." Añade el art. 45.2 del RDUCA que a efectos del cómputo de ese plazo no se computarán las dilaciones o suspensiones del procedimiento que sean imputables al presunto responsable. En todo caso, en el supuesto de que las obras fuesen legalizables y el interesado inste la legalización en el plazo de dos meses que se le haya concedido, la tramitación del procedimiento de protección de la legalidad se suspenderá hasta la resolución del procedimiento de legalización (art. 47.2 RDUCA), que en principio tendrá la duración máxima prevista para el otorgamiento de las licencias urbanísticas, esto es, tres meses (art. 172.5 LOUA).

Por último, en cuanto a la naturaleza de este plazo es reiterada la jurisprudencia que lo califica como de caducidad (Sentencias del TSJ de Andalucía de 16 de noviembre de 1999, LA LEY 163154/1999, de 30 de julio de 2002, LA LEY 142609/2002, de 4 de mayo de 2007, LA LEY 263222/2007, o Sentencia del TSJ de Cataluña de 25 de marzo de 2009, LA LEY 172480/209)), por consiguiente cabrá su suspensión, pero no su interrupción.

B. Plazo dentro del cual ha de ejercerse la potestad de protección de la legalidad urbanística.

a). El plazo general de caducidad de seis años y la excepción de inexistencia de plazo.

Las medidas, bien sean cautelares o definitivas, de protección de la legalidad urbanística y restablecimiento del orden jurídico perturbado sólo podrán adoptarse mientras los actos estén en curso de ejecución, realización o desarrollo, y dentro de los seis años siguientes a su completa terminación (art. 185.1 LOUA y 46 RDUCA). La redacción originaría del art. 185.1 LOUA establecía el tradicional plazo de cuatro años, la ampliación a seis años se ha debido a la reforma operada en virtud de la Ley 2/2012, de 30 de enero. Como quiera que esta norma no ha establecido expresamente el momento de su entrada en vigor deberemos entender que entró en vigor a los veinte días de su completa pu- 
blicación, conforme a lo dispuesto en el art. 2.1 del Código Civil. Por tanto, si la Ley se publicó en el BOJA de 8 de febrero de 2012, entró en vigor, curiosamente, el día de Andalucía. Esta ampliación del plazo de que dispone la Administración para el ejercicio de la potestad de protección de la legalidad urbanística es una norma desfavorable no cabiendo, por consiguiente, su aplicación retroactiva tal y como dispone el art. 9.3 de nuestra Constitución. Quiere decirse que sólo quedarán sujetas al nuevo plazo aquellas actuaciones que se hayan iniciado o hayan terminado bajo la vigencia de la nueva ley. El resto de actuaciones, es decir, las iniciadas y terminadas antes el 28 de febrero de 2012, continuarán sujetas al plazo originario de cuatro años.

Ahora bien, esta limitación temporal, antes de cuatro y ahora de seis años, no regirá para los atentados más graves a la legalidad urbanística que vienen previstos en el art. 185.2 de la LOUA, cuya restauración no está sujeta a plazo y, por tanto, puede llevarse a cabo en cualquier momento. Se trata de:

- Los actos de parcelación urbanística en terrenos que tengan la consideración de suelo no urbanizable.

- Los actos que afecten a terrenos clasificados como suelo no urbanizable de especial protección o incluidos en la Zona de Influencia del Litoral.

- Los actos que afecten a bienes o espacios catalogados.

- Los actos que afecten a parques, jardines, espacios libres o infraestructuras o demás reservas para dotaciones.

- Las determinaciones pertenecientes a la ordenación estructural de los Planes Generales de Ordenación Urbanística o de los Planes de Ordenación Intermunicipal.

Nos encontramos, nuevamente, ante un plazo de caducidad y no de prescripción, por lo que, no cabe su interrupción, sino sólo su suspensión. Al respecto pueden verse las Sentencias del TSJ de Andalucía de 15 de febrero de 2007, LA LEY 273549/2007, 28 de noviembre de 2008, LA LEY 254883/2008, 17 de julio de 2009, LA LEY 242177/2009, 25 de febrero de 2010, LA LEY 57552/2010 y 23 de septiembre de 2010, LA LEY $254360 / 2010$.

\section{b). El comienzo del plazo y la terminación de las obras.}

En todo caso el comienzo del cómputo de este plazo de seis años precisará que las obras o usos se manifiesten mediante la aparición de signos externos que permitan conocer los hechos constitutivos de la infracción. Podemos distinguir distintos supuestos. 
- Obras en curso de ejecución que estén paralizadas:

Si se trata de obras en curso de ejecución que se encuentren paralizadas cautelarmente, la fecha para el comienzo del cómputo de este plazo será aquélla en la que la Administración acordó la suspensión de las obras (art. 46.1 RDUCA).

- Obras que no han sido paralizadas:

Si las obras no han sido paralizadas, por consiguiente, deberemos entender que el Ayuntamiento no ha tenido conocimiento de la vulneración de la legalidad urbanística pues la potestad de protección de la legalidad urbanística es obligatoria (art. 192.2 LOUA), tendremos que distinguir, a su vez, según el art. 40 del RDUCA dos supuestos:

. Si se trata de obras amparadas por licencia, se considerará que están totalmente terminadas, cuando se trate de obras que cuenten con proyecto técnico, a partir de la fecha del visado del certificado final de obras, suscrito por el facultativo o facultativos competentes, y a falta de este documento, desde la fecha de notificación de la licencia de ocupación o utilización. Si se tratase de obras promovidas por las Administraciones Públicas, a partir de la fecha del acta de recepción de las obras. En los demás casos, desde que el titular de la licencia comunique al Ayuntamiento la finalización de las obras.

. Si se trata de obras sin licencia, para determinar su fecha de terminación será admisible cualquier medio de prueba. La carga de la prueba de su terminación corresponderá al titular de las obras quien, en su caso, deberá desvirtuar las conclusiones que resulten de las comprobaciones realizadas por los servicios técnicos correspondientes. Tales obras se considerarán terminadas cuando estén ultimadas y dispuestas a servir al fin previsto, sin necesidad de ninguna actuación material posterior referida a la propia obra, salvo las posibles obras de adaptación de algunos locales. También se considerarán terminadas cuando así lo reconozca de oficio el órgano que incoe el procedimiento, previo informe de los servicios técnicos correspondientes.

c). El transcurso del plazo de seis años y la asimilación a la situación de fuera de ordenación.

¿Qué pasa si transcurre el plazo de seis años y el Ayuntamiento no ha reaccionado? La LOUA había guardado silencio al respecto. Ha sido el RDUCA el que ha regulado tal supuesto en su art. 53.4 al decir que "La resolución dictada por el órgano competente, por la que se acuerde el transcurso del plazo previsto para adop- 
tar medidas de protección o restauración de la legalidad urbanística, o el cumplimiento por equivalencia en caso de imposibilidad legal o material de ejecución de la resolución en sus propios términos, declarará el inmueble afectado en situación de asimilación a la de fuera de ordenación, identificando las circunstancias que la motivan y el régimen jurídico aplicable al mismo, con indicación expresa de que sólo podrán realizarse las obras de reparación y conservación que exija la estricta conservación de la habitabilidad o la utilización conforme al destino establecido. Excepcionalmente podrán autorizarse obras parciales y circunstanciales de consolidación, cuando no estuviera prevista la expropiación o demolición, según proceda, en un plazo de cinco años, a partir de la fecha en que se pretenda realizarlas. La Administración pública competente estará facultada para instar la constancia de dicha resolución en el Registro de la Propiedad en la forma y a los efectos en la legislación correspondiente."

Por último, el $\mathrm{n}^{\circ} 5$ de este mismo artículo reconoce que podrán concederse licencias en los supuestos contemplados en este precepto, a saber, obras sobre las que ya no se puedan adoptar las medidas de protección de la legalidad urbanística por haber transcurrido el plazo de seis años, y obras en las que resulte imposible material o legalmente ejecutar la resolución de reposición de la realidad física alterada. No obstante, estas licencias estarán sujetas a ciertos límites:

- Describirán la situación de asimilación a la de fuera de ordenación por el transcurso del plazo previsto para adoptar medidas de protección o restauración de la legalidad urbanística o por imposibilidad legal o material de ejecución en sus propios términos de la resolución de un procedimiento para la protección de la legalidad urbanística.

- Precisarán el régimen jurídico aplicable a las mismas.

- Se otorgarán bajo la condición de su constancia en el Registro de la Propiedad.

- $\quad$ En el supuesto de imposibilidad material o legal de ejecución, tales licencias sólo serán otorgadas en el caso de que la indemnización por equivalencia que se hubiere fijado hubiese sido íntegramente satisfecha.

En realidad, lo que ha hecho el RDUCA ha sido acoger la doctrina que al respecto ya había sentado el TS de la que resulta un buen exponente la Sentencia de 3 de abril de 2000, LA LEY 73824/2000, en la que manifestaba el Alto Tribunal que "...Si las circunstancias urbanísticas que debieron ser objeto de licencia de obras no pueden revisarse al examinar una petición de licencia de primera utilización, tampoco cabe denegar ésta cuando pese a haberse erigido una edificación sin licencia y en contra del planeamiento, ha caducado el plazo concedido a la Administración para el ejercicio de su potestad de restablecimiento de la legalidad urbanistica y el uso pretendido se encuentra entre los autorizados en la zona. 
La consecuencia expuesta no implica la legalización de la obra ejecutada, sino el mantenimiento del uso que de hecho ha estado llevándose a cabo en ella desde su construcción, y ni siquiera supone una traslación automática para aquella edificación del régimen establecido en el artículo 60.1 del Texto refundido de la Ley del Suelo de 9 Abr. 1976 (Tr Ls) puesto que, como ha declarado esta Sala en sentencia de 15 Feb. 1999, «lo construido sin licencia y en contra de la normativa urbanística puede considerarse como fuera de ordenación, en el sentido de que no se ajusta ala legalidad urbanística, pero se diferencia del supuesto de hecho previsto en el artículo 60.1 Trls en que las obras eran ya ilegales en el momento mismo en que se estaban llevando a cabo», por lo que «el transcurso del plazo de cuatro años desde la ejecución de las obras sin licencia o contrarias al planeamiento impide al Ayuntamiento la adopción de medidas de restablecimiento de la legalidad urbanística prevista en el artículo $184.3 \mathrm{Tr} \mathrm{Ls}$, pero no otorga al propietario de las mismas otras facultades que las inherentes al mantenimiento de la situación creada, esto es la de oponerse a cualquier intento de demolición de lo construido o de la privación del uso que de hecho está disfrutandon, siempre que este uso no se oponga al permitido por el plan para la zona de que se trata..."

\section{Plazo para llevar a cabo la demolición acordada.}

Por último, cabe plantearse cuál es el plazo para llevar a efecto la demolición acordada, es decir, para ejecutar esa decisión. Por extraño que parezca, ni la LOUA ni la precedente legislación urbanística estatal se han preocupado de regular este plazo. Sin embargo, la jurisprudencia ha considerado que resulta aplicable el plazo de 15 años previsto en el art. 1964 del Código Civil para el ejercicio de las acciones personales que no tengan señalado término especial de prescripción. Así por ejemplo, el TSJ de Madrid en Sentencia de 13 de marzo de 2007, LA LEY 148562/2007, ha declarado que “...no habiendo sido anulado por los tribunales ni objeto de procedimiento de revisión de oficio alguno la orden de demolición conserva su ejecutividad y debe señalarse que una vez acordada la demolición el plazo para su ejecución es de quince años desde que se dictó la orden de demolición, así lo señala la Sentencia del Tribunal Supremo de 5 de junio de 1987, y lo ha venido sosteniendo esta Sección inveteradamente señalando a efectos ilustrativos la sentencia de 5 de abril de 2005, al entender que la prescripción de una orden administrativa de derribo firme no tiene lugar hasta el transcurso del plazo de los 15 años prevenido en el artículo 1964 del Código Civil contado a partir de la fecha en que el acto quedó firme, de modo análogo a lo que ocurre con la prescripción de las ejecutorias (art. 4.1 del Código Civil) para las que los Autos de esta Sala de 16 de octubre de 1976 y 11 de julio de 1985 ya tiene aplicado el aludido plazo..." En idéntico sentido se ha pronunciado el TS en Sentencia de 17 de febrero de 2000, LA LEY 5626/2000, al declarar que "... La cuestión debe analizarse desde los principios generales que regulan la ejecución de los actos administrativos y en este sentido es de ver que conforme a los articulos 44 y 101 de la LPA los actos de la Administración son inmediatamente ejecutivos, lo que significa que deben llevarse a efecto de manera inmediata, 
pues toda demora irrazonable pudiera ir contra lo dispuesto en el artículo 103 de la Constitución y en concreto contra el principio de eficacia impidiendo cumplir el fin de servir con objetividad los intereses generales que constituyen el soporte de la actuación de la Administración pública.

Por ello, aunque ni la legislación específica urbanística ni la general de procedimiento administrativo prevean plazos de prescripción para ejecutar lo acordado, el principio expuesto, junto a los de seguridad jurídica y de interdicción de la arbitrariedad de los poderes públicos (artículo 9.3 de la Constitución) fuerzan a entender que la ejecución forzosa se halla sujeta a plazos de prescripción. En la medida en que el acto administrativo ordenó al constructor el derribo de un edificio, aquél contiene una obligación de hacer, la exigencia de cuya efectividad no puede quedar indefinidamente pendiente en el tiempo sino que por tratarse, en definitiva, de una obligación personal está sujeta al plazo de prescripción de quince años del artículo 1964 del Código Civil, que es el plazo de que la Administración disponía para acudir al mecanismo de ejecución subsidiaria y que fue largamente sobrepasado en el presente caso..."

\section{LIGENGIAS U ÓRDENES DE EJEGUCIÓN INCOMPATI- BLES GON LA ORDENACIÓN URBANÍSTICA}

\section{Planteamiento.}

Aquí el supuesto es totalmente distinto a los casos que hasta el momento hemos analizado. Se trata ahora de supuestos en los que nos encontramos con una determinada obra o actuación, ya realizada o en curso de realización, pero que se encuentra amparada por la correspondiente licencia, es decir, que está amparada por el correspondiente título habilitante, por el correspondiente acto administrativo, pero dicho acto es ilegal, o sea, está viciado. En estos supuestos para restaurar la legalidad urbanística habrá que anular previamente el acto administrativo en cuya virtud se otorgó la licencia o se emitió la orden de ejecución. Este supuesto específico se encuentra regulado en los arts. 189 y 190 de la LOUA desarrollados por los arts. 57 y 58 del RDUCA, regulación que habrá que poner en relación con los preceptos de la LPAC que se ocupan de la revisión de los actos en vía administrativa (arts. 102 a 119).

\section{Supuestos que pueden darse.}

A. Anulación de la licencia u orden de ejecución a instancia del interesado mediante la interposición de un recurso administrativo o solicitud de revisión de oficio del art. 102. LPAC. 
La licencia, como cualquier acto administrativo puede ser anulada a instancia de cualquier interesado, máxime si tenemos en cuenta que en esta materia existe acción pública ${ }^{15}$ (art. 48 Texto Refundido de la Ley de Suelo de 2008), por lo que cualquier ciudadano podrá formular recurso administrativo, generalmente de reposición, o instar del Ayuntamiento la incoación del expediente de revisión de oficio de una licencia que considere está viciada de nulidad absoluta. Tanto en el procedimiento de recurso administrativo, como en el de revisión de oficio se podrán adoptar las medidas cautelares o provisionales que se consideren convenientes para asegurar la eficacia de la resolución que pudiera recaer (art. 72 y 104 LPAC), entre las que se encuentran lógicamente la paralización de las obras que estén en curso de ejecución. Debemos tener en cuenta que si la licencia se anula en un procedimiento de revisión de actos nulos de pleno derecho se puede dar la paradoja de que la licencia quede efectivamente anulada, aun cuando hayan transcurrido más de seis años desde el otorgamiento de la licencia, dado que estos procedimientos de revisión no están sujetos a plazo, pero en tales supuestos no se podría llevar a cabo la reposición de la realidad física alterada, la cual se encuentra, como ya vimos, sujeta al plazo de seis años para su ejercicio, salvo que se tratase de uno de los supuestos previstos en el art. 185.2 de la LOUA que tampoco se encuentran sujetos a plazo.

Evidentemente, si la Administración desestima el recurso administrativo o la solicitud de revisión de oficio, esa decisión administrativa será recurrible ante la Jurisdicción Contencioso-administrativa.

B. Anulación de la licencia u orden de ejecución a instancia de la propia Administración siguiendo los cauces de la revisión de oficio.

En el caso de que la licencia sea nula de pleno derecho el Ayuntamiento podrá incoar de oficio el procedimiento de revisión en cualquier momento, siguiendo los cauces del art. 102 de la LPAC, pudiendo adoptar las medidas cautelares que considere convenientes, incluida la suspensión de las obras, conforme a lo dispuesto en los arts. 72 y 104 de la LPAC.

${ }^{15} \mathrm{Al}$ respecto de la acción pública en materia urbanística resulta muy interesante la lectura de la Sentencia del TSJ de Andalucía de 17 de julio de 2009, LA LEY 242177/2009, en cuyo fundamento jurídico primero "in fine" podemos leer que "... La acción pública anteriormente descrita sólo está prevista en materia urbanística, por lo que sólo sería ejercitable frente a licencia de obra concedida con infracción de los Planes y Programas Urbanísticos. No es aplicable en cambio, ni a la licencia de instalación ni a la de funcionamiento, que no forman parte de la legislación urbanística, estando en éste caso solamente legitimados para la impugnación, quienes ostentan la conceptualización de interesados, de acuerdo con lo dispuesto en el art. 19.1.a) en relación con el apartado h) de la Ley 29/1998, de 13 de julio, no estando prevista la acción popular en materia de instalaciones para el ejercicio de una actividad." 
Si la licencia fuera meramente anulable, dentro de los cuatro años siguientes a su otorgamiento, el Ayuntamiento podrá declarar su lesividad (art. 103 LPAC) y a continuación formular el correspondiente recurso contencioso-administrativo.

Estos dos supuestos que acabamos de comentar se encuentran regulados en el art. 190 de la LOUA y 58 del RDUCA, aunque de una forma defectuosa, pues confunden los vicios de los actos administrativos con la gravedad de las infracciones que dichos vicios pueden llevar aparejadas, pues dice el art. 190.1 que "... las licencias urbanísticas y la órdenes de ejecución, así como cualquier otro acto administrativo previsto en esta Ley, cuyo contenido constituya o habilite de manera manifiesta alguna de las infracciones urbanisticas graves o muy graves definidas en esta Ley, deberán ser objeto de revisión por el órgano competente, de conformidad con lo establecido en la legislación reguladora del régimen jurídico de las Administraciones públicas y del procedimiento administrativo común."

Idénticas previsiones a las realizadas anteriormente cabe efectuar aquí en cuanto a la limitación temporal a que se encuentran sujetas las medidas de protección de la legalidad urbanística y restablecimiento del orden jurídico perturbado.

C. Anulación de la licencia u orden de ejecución a instancia de la Administración del Estado o de la Junta de Andalucía.

Tanto la Administración del Estado como la de la Junta de Andalucía podrán instar la anulación de una licencia ante la Jurisdicción Contencioso-administrativa siguiendo los cauces previstos en los arts. 65 y 66 de la LBRL.

Además el RDUCA ha puesto en manos de la Junta de Andalucía otra posibilidad de reacción contra las licencias ilegales al decir en su art. 58.3 que "Sin perjuicio de lo establecido en la legislación de régimen local, la Consejería con competencia en materia de urbanismo podrá instar de las Corporaciones Locales la declaración de nulidad de los actos a los que se refiere el apartado primero, así como impugnar la desestimación expresa o presunta de las solicitudes que hubiere instado, en los términos y plazos previstos por la legislación de procedimiento administrativo común y de la jurisdicción contencioso-administrativa." O sea, se le está permitiendo a la Junta de Andalucía actuar como cualquier otro interesado usando el régimen normal de solicitud de revisión por los cauces del art. 102 de la LPAC, y contra la desestimación expresa o presunta de la misma podrá interponer el correspondiente recurso contencioso-administrativo. Sin duda esta previsión pretende facilitar la reacción de la Comunidad Autónoma dado que los plazos previstos en los arts. 65 y 66 de la LBRL 
son más reducidos que los generales previstos en la LPAC para reaccionar contra los actos nulos o anulables.

Sigue siendo válido lo dicho antes respecto a las limitaciones temporales a que está sujeta el ejercicio de la potestad de restauración de la legalidad urbanística.

D. Suspensión por el Alcalde de las obras en curso de ejecución amparadas por una licencia u orden de ejecución.

Los supuestos antes vistos son en realidad aplicación del sistema general de revisión de los actos administrativos al caso concreto de las licencias urbanísticas u órdenes de ejecución, excepción hecha de la novedad introducida por el art. 58.3 del RDUCA.

El caso que ahora nos ocupa aparece específicamente regulado ${ }^{16}$ en el art. 189 de la LOUA y 57 del RDUCA, preceptos que habrá que poner en conexión con el art. 127 de la LJCA. Dice el art. 189 de la LOUA lo siguiente:

"1. El Alcalde, de oficio o a solicitud de cualquier persona, así como a instancia de la Consejería competente en materia de urbanismo en los casos previstos en el artículo 188.1, dispondrá la suspensión de la eficacia de una licencia urbanística u orden de ejecución y, consiguientemente, la paralización inmediata de los actos que estén aún ejecutándose a su amparo, cuando el contenido de dichos actos administrativos constituya o legitime de manera manifiesta alguna de las infracciones urbanisticas graves o muy graves definidas en esta Ley.

2. El Alcalde procederá a dar traslado directo de la resolución de suspensión al órgano jurisdiccional competente, en los términos y a los efectos previstos en la legislación reguladora de la jurisdicción contencioso-administrativa."

Respecto a este precepto tenemos que realizar, algunos comentarios:

En primer lugar, el objeto de este recurso contencioso-administrativo, que aparece específicamente regulado en el art. 127 LJCA, no es solo el acuerdo de suspensión de la licencia dictado por el Alcalde, sino también el acto o acuerdo suspendido, o sea, la licencia urbanística concedida. Así lo ha declarado la STSJ de Andalucía de 18 de mayo de 2009, LA LEY 182071/2009, y la STS

${ }^{16}$ Este supuesto específico ya aparecía regulado en el art. 186 del Texto Refundido de la Ley de Suelo de 1976 y en el art. 253 del Texto Refundido de la Ley de Suelo de 1992. 
de 21 de marzo de 2006, LA LEY 48552/2006. Además, hay que tener presente que para poder utilizar este cauce procedimental la licencia u orden de ejecución ha de constituir o legitimar de manera manifiesta alguna de las infracciones graves o muy graves definidas por la LOUA; por consiguiente, si dichos actos administrativos no son constitutivos de una infracción grave o muy grave no se podrá acudir al procedimiento que nos ocupa tal y como ha declarado el TS en Sentencia de 21 de marzo de 2006, LA LEY 48552/2006, al indicar que "...Para hacer uso de la potestad de suspender los efectos de una licencia, conforme a lo establecido en el art. 186 del Texto Refundido de la Ley del Suelo de 1976 y 184 de la Ley de Ordenación del Territorio de Canarias, no basta que dicha licencia se haya concedido con vulneración de determinados preceptos del ordenamiento jurídico, que pudieran acarrear su revisión de oficio o a petición de cualquier interesado, como parece ser aqui ha sucedido mediante otro acuerdo del Pleno municipal adoptado el día 10 de junio de 2002, que es objeto de otra impugnación en sede jurisdiccional, sino que es imprescindible que el otorgamiento de tal licencia constituya una infracción urbanística grave, asi definida o tipificada legalmente, o que infrinja la zonificación o uso urbanistico de las zonas verdes o espacios libres previstos en los planes, como esta Sala del Tribunal Supremo declaró entre otras, en su Sentencia de 16 de mayo de 1998 (LA LEY 5778/1998)..." De lo dicho hasta ahora debemos colegir que el procedimiento de suspensión previa de acuerdos que estamos analizando es diferente e incluso compatible con los procedimientos de revisión de oficio de actos nulos o anulables. En este sentido resulta muy interesante el fundamento jurídico tercero de la STSJ de Andalucía de 18 de mayo de 2009, LA LEY 182071/2009, al enseñar que “...Son dos procesos distintos de tal manera que la posibilidad de las Corporaciones locales de acudir a los procedimientos de lesividad o revisión no impide al Alcalde la suspensión de los efectos de una licencia cuando constituya manifiestamente una infracción urbanística grave, y es que el Artículo 103 de la ley 30/92 establece que las Administraciones públicas podrán declarar lesivos para el interés público los actos favorables para los interesados que sean anulables conforme a lo dispuesto en el art. 63 de esta Ley, a fin de proceder a su ulterior impugnación ante el orden jurisdiccional contencioso-administrativo.

La Sentencia del TS7 de Málaga de 24-11-2006, analiza la diferencia objetiva de las pretensiones esgrimidas a través de uno y otro procedimiento, y la compatibilidad entre ambos, es decir, el proceso de lesividad, y el seguido a través del procedimiento especial del artículo 127 de la Ley Jurisdiccional, señalando que tales diferencias lo son además de por el hecho de poder ser distintas las fundamentaciones de ambos procedimientos, porque dicho procedimiento especial se basa en el ejercicio por la Administración de una especial potestad de suspensión previa del acuerdo impugnado, cuya legalidad debe también dilucidarse a través de aquel procedimiento especial, hasta el punto de poder terminar con su declaración de nulidad.... 
En consecuencia, aunque ambos procesos compartan elementos comunes, lo cierto es que sus respectivos objetos no coinciden plenamente, lo que, consecuentemente, descarta la aplicación de la excepción prevista por el artículo 69.b) de la Ley 29/1998, sin que, esta conclusión se contradiga con la posible pérdida de objeto que la resolución de uno de los procesos pueda provocar sobre el otro como consecuencia propia de la eficacia material de la sentencia, que puede suponer la desaparición del acto impugnado en relación con cualquier persona afectada (artículo 72.2 Ley 29/1998), no sólo de quienes intervengan como partes en el proceso en que se dicte $y$, por tanto, con un alcance muy distinto del que debe reconocerse a los efectos jurídico-procesales de la resolución judicial, entre otros, a la cosa juzgada o a la jurisprudencia.

Esto es, nada se opone en principio a la posibilidad de los Ayuntamientos para que una vez utilizada la facultad de suspensión usen otras facultades como las de revisión de oficio y así lo expresaba ya la Sentencia del TS de 1-2-2001 y la de 21-3-2006 esta última diciendo que "frente a aquella vía especial de suspensión previa se refiere como cuestión distinta al procedimiento de revisión de oficio en el que el órgano competente para resolver proceda a suspender la ejecución del acto cuando éste pudiera causar perjuicios de imposible o dificil reparación, supuesto diferente de aquel otro, que se contrae al uso de la potestad de suspender los efectos de una licencia con la consiguiente paralización de las obras, contemplada en el artículo 186.1 y 3 del Texto Refundido de la Ley del Suelo de 1976, en relación con el artículo 127 de la Ley de esta Jurisdicción, "...muy distinto de la revisión de oficio prevista en los artículos 302 del Texto Refundido de la Ley del suelo de 1992, declarado vigente por la Ley 9/98, de 13 de abril , y 102 a 106 de la Ley 30/1992, de 26 de noviembre, de Régimen Furídico de la Administraciones Públicas y del Procedimiento Administrativo Común.

Como conclusión, siendo la anulación de la licencia objeto propio del proceso seguido a través del artículo 127 LFCA que pretende no solo la ratificación de una medida cautelar sino que se efectúe un pronunciamiento expreso sobre la licencia en cuanto pudiera amparar una infracción manifiesta y grave, y el pronunciamiento compatible con el inicio del proceso de lesividad, deben decaer los motivos de impugnación de la Sentencia apelada que se confirma, sin que el pronunciamiento sobre la anulación de la licencia afecte a la competencia del Pleno en orden a resolver el proceso de lesividad ya iniciado..."

En segundo lugar, en los diez días siguientes a la fecha en que se hubiera dictado el acto de suspensión (art. 127.2 LJCA), el Ayuntamiento deberá interponer recurso contencioso-administrativo mediante escrito fundado, por tanto, no es un mero escrito de recurso contencioso-administrativo, o bien puede dar traslado directo al órgano judicial del acuerdo suspendido, es decir, la licencia, acompañando en uno y otro caso copia del acto por el que se acuerda la suspensión de la licencia. Respecto a la naturaleza de este plazo, la STSJ de Andalucía de 25 de abril de 2011, LA LEY 167274/2011, ha declarado que “...al no constar que sea aplicable legalmente otro por establecerlo una Ley, es considerado como pla- 
zo procesal en la Furisprudencia como se deduce de la sentencia de varios Tribunales Superiores de Fusticia, como la sentencia del TS7 de Canarias de 26 de julio de 2000, en la que se señala que este plazo no solo es un requisito procesal sino del proceso, de cuyo cumplimiento depende la admisibilidad del procedimiento, ya que el mismo precepto condiciona la eficacia de la medida a que en el término de diez días se de traslado de la suspensión a los órganos jurisdiccionales de lo Contencioso administrativo, para la incoación del proceso especial, de forma que no habiéndose cumplido el plazo, la suspensión acordada habia dejado de tener efecto por falta de cumplimiento de esta condición legal, procediendo levantar la suspensión, no obstante sin entrar a decidir sobre la legalidad o anulación del acuerdo, basándose el levantamiento de la suspensión en la falta de un requisito indispensable para su eficacia; además este plazo también es el previsto en el artículo 67 de la Ley 7/1985, de 2 de abril, reguladora de las Bases de Régimen Local. Ello, en consecuencia, se configura como una excepción a lo dispuesto en el artículo 51 de la misma Ley ..."

Iniciado el procedimiento jurisdiccional, de una u otra forma, el Juzgado de lo Contencioso-administrativo, que es el competente para conocer de estos asuntos, requerirá al Ayuntamiento para que le remita el expediente administrativo en el plazo de diez días. Entiendo que deberá remitir, tanto el expediente que se instruyó para otorgar la licencia, como el que se ha instruido para suspenderla. Al enviar el expediente administrativo, el Ayuntamiento podrá hacer las alegaciones que estime oportunas en su defensa, aunque si formuló recurso estas alegaciones no tienen sentido, pues es de suponer que ya las realizó al interponerlo. Además deberá notificar la existencia del recurso a todos cuantos tuvieran interés legítimo en el mantenimiento (especialmente el titular de la licencia) o anulación de la licencia, para que puedan comparecer ante el órgano jurisdiccional en el plazo de diez días.

Recibido el expediente, el órgano judicial lo pondrá de manifiesto junto con las actuaciones a los comparecidos en el procedimiento, convocándolos para la celebración de una vista, que tendrá lugar como mínimo a los diez días de la puesta de manifiesto del expediente. No obstante, el órgano judicial podrá sustituir, motivadamente, el trámite de vista por el de alegaciones escritas, que se presentarán en el plazo común de los diez días siguientes a la notificación del auto en que así se acuerde. También podrá abrir un periodo de prueba, para mejor proveer, por plazo no superior a quince días.

Celebrada la vista o deducidas las alegaciones, se dictará Sentencia que deberá contener necesariamente "...el pronunciamiento relativo a la suspensión de la efectividad de la licencia y paralización de la obra, pero también y alternativamente un pronunciamiento sobre la anulación del título controvertido..." (STSJ de Andalucía de 18 de mayo de 2009, LA LEY 182071/2009). O sea, la Sentencia debe anular o con- 
firmar la licencia. Si la anula confirmará también la suspensión, pero si la confirma, deberá levantar la suspensión. Así lo ha declarado el TS en Sentencia de 21 de marzo de 2006, LA LEY 48552/2006, al señalar que “... lo cierto es que el art. 127.6 de la vigente Ley Furisdiccional, al regular el procedimiento en los casos de suspensión administrativa previa de acuerdos, impone el deber de dictar sentencia que anule o confirme el acto o acuerdo del recurso, disponiendo, a su vez, lo que proceda en cuanto a la suspensión..."

\section{Consecuencias que se derivan de los anteriores procedimientos.}

Las actuaciones que se lleven a cabo en los anteriores procedimientos son independientes de las de carácter sancionador (arts. 189.3 LOUA, 57.3 y 58.2 RDUCA).

Si en los procedimientos anteriores se adopta la medida provisional de suspensión de los efectos de la licencia, se podrá adoptar también la medida de suspensión de la tramitación de las de ocupación o utilización y la prestación de servicios contratados con empresas suministradoras. Medidas que serán preceptivas en el supuesto de suspensión de las obras en curso de ejecución por el Alcalde (art. 189.4 LOUA y 57.4 RDUCA).

Todos los actos de suspensión y anulación de licencias, o reposición de la realidad física alterada podrán ser inscritas en el Registro de la Propiedad (art.177.1.f, g, h, i , j, LOUA).

A estos supuestos también se les aplicará los beneficios derivados de la voluntaria restauración de la legalidad urbanística o reposición de la realidad física alterada.

Finalmente, anulada la licencia u orden de ejecución, o aquél acto o acuerdo que ampare el derecho a construir, edificar o urbanizar, la Corporación Local procederá a restablecer el orden jurídico vulnerado, ordenando la inmediata reposición de la realidad física alterada al amparo del título anulado con adopción de algunas de las medidas previstas en el art. 49.2 del Reglamento, sin perjuicio de las responsabilidades que sean exigibles conforme a lo dispuesto en la LPAC. No obstante, si hubiera transcurrido el plazo de seis años a que queda sujeta la potestad de restauración de la legalidad urbanística, la edificación deberá quedar en situación asimilada a la de fuera de ordenación. 


\section{CONGLUSIONES}

La valoración de la regulación llevada a cabo en Andalucía de la potestad de protección de la legalidad urbanística y restablecimiento del orden jurídico perturbado necesariamente ha de ser positiva. Se trata de una regulación completa y ordenada que ha sabido respetar la herencia que ha dejado una sólida normativa estatal, lo cual infunde seguridad, de la que tan necesitados estamos en estos tiempos, a los operadores jurídicos y económicos de este importante sector jurídico-económico que es el urbanismo. No obstante, se trata de una regulación tardía, pues entre la Ley y el Reglamento mediaron más de ocho años, aunque valdría aquello de "nunca es tarde si la dicha es buena" o "bien está lo que bien acaba". En definitiva, el marco normativo ideado por el legislador andaluz y desarrollado por su gobierno es suficiente y adecuado a nuestra realidad, si bien cabe preguntarse si la responsabilidad principal del ejercicio de esta importante potestad puede o debe recaer en los pequeños municipios de nuestra geografía, y entendamos por pequeños a estos efectos, los de menos de veinte mil habitantes, o bien, si estas potestades, tan difíciles de ejercer dada la cercanía del "vecino" con respecto a los gestores municipales y los potentes intereses en conflicto, deberían haberse puesto directamente en manos de otros entes con mayor capacidad técnica y de gestión, como son la propia Comunidad Autónoma o las tan denostadas Diputaciones, que para algo las tenemos, máxime si hoy en día lo que está en tela de juicio no es meramente la autonomía local, sino la propia soberanía nacional. Ya se verá.

\section{BIBLIOGRAFÍA}

- $\quad$ BERMEJO VERA, José y otros, Derecho Administrativo Parte Especial, Civitas, Madrid, 1998.

- $\quad$ GARCELLER FERNÁNDEZ, Antonio, Introducción al Derecho Urbanístico, Tecnos, Madrid 1992. Manual de Disciplina Urbanística, Tecnos, Madrid, 1983.

- $\quad$ Gastillo Blanco, Federico, Derecho Urbanístico de Andalucía, Tirant Lo Blanch, Valencia 2003.

- $\quad$ FERNÁNDEZ RODRÍGEZ, Tomás-Ramón, Manual de Derecho Urbanístico, El Consultor, Madrid, 2008.

- GONZÁlEZ PÉREZ, Jesús, Comentarios a la Ley de Suelo, Civitas, Madrid, 1988. 
- GUTIÉRREZ COLOMINA, Venancio y GUTIÉRREZ JULIÁN, Francisco Javier, Comentario sobre el Reglamento de Disciplina Urbanística de Andalucía, Fundación Asesores Locales, Málaga 2011.

- $\quad$ LLISET BORRELL, Francisco y otros, Ley de Suelo. Comentarios al Texto Refundido de 1992, El Consultor, Madrid, 1993.

- $\quad$ PAREJO ALFONSO, Luciano y ROGER FERNÁNDEZ, Gerardo, Comentarios a la Ley de Suelo, Iustel, Madrid, 2008.

- $\quad$ RebOllo PUIG, Manuel, y otros, Derecho Urbanístico y Ordenación del Territorio en Andalucia, Iustel, Madrid, 2007.

- $\quad$ RIVERO YSERN, José Luis, Manual de Derecho Local, Civitas, Cizur Menor (Navarra) 2010.

- $\quad$ SÁNCHEZ GOYANES, Enrique y otros, Derecho Urbanístico de Andalucía, El Consultor, Madrid, 2004.

- $\quad$ TOLOSA TRIBIÑO, César, El Uso del Suelo, DAPP, Pamplona, 2006. 